\author{
Weronika Górnicka* \\ University of Zielona Góra, Zielona Góra, Poland \\ https://orcid.org/0000-0001-8975-1692

\section{Transposition of a national sports event into a transnational one on the example of the Spanish El Clásico}

\title{
Introduction
}

In one of the interviews, the Spanish journalist Alfredo Relaño, author of the book Nacidos para incordiarse: un siglo de agravios entre el Madrid y el Barça, stated that "Barca is a sentimental issue, while Real is a tool of conquest [...]. Love for Barca is much purer, one loves it regardless of the worse times" (Ruiz, Martiarena, 2012). This diversity, exposed by confronting different styles of club management and team building, is visible in the promotion of the fundamental elements that determine the identity of both teams. Situating them on two extreme positions in the axiological area determines certain sympathies and creates an inseparable bond resulting from the creation of an antagonistic relation. The direct confrontation of these two ideas, expressed in El Clásico matches, is the culminating moment in the settlement and determination of the dominant entity. Analyzing this situation only in the perspective of the Spanish symbolic and sporting space, where this confrontation is an extension and expression of the SpanishCatalan conflict, the high level of interest in the meetings is obvious. In 2018, however, live coverage was carried out in 183 countries, which translated into about 650 million viewers on five continents (El Clasico, 2019). The high emotional commitment and sympathy for both clubs is also confirmed by the statistics of the peñas, the official fan clubs created outside Spain - according to data for 2018, Barca has 134 branches in 65 countries on five continents (Memoria 2018/2019 FC Barcelona, 2019: 133) and the Los Blancos 201 in 84 countries on five continents (Informe Annual Real Madrid, 2019: 66-67). This high level of interest is most often associated with the marketing activities of both clubs, which after 2000 can be considered one of the most effective in terms of team promotion. These issues are an important factor, but in this study the analysis will focus on activities consciously or unconsciously aimed at making a national event, or El Clásico, an export commodity that not only arouses interest, but also emotionally links the inhabitants of other countries with an entity with a separate location and history.

\footnotetext{
* Correspondence address: Instytut Nauk o Polityce i Administracji, Uniwersytet Zielonogórski, Al. Wojska Polskiego 69, 65-762 Zielona Góra, Polska, e-mail: w.gornicka@gmail.com.
} 
The purpose of the research problem constructed within the framework of the article - how the national event, or El Clásico, was transposed to a transnational event - is the final verification of the hypothesis, which assumes that while still operating in the Spanish symbolic space Real Madrid and FC Barcelona have transposed the mutual rivalry through the permutation of the national event into transnational, using for this purpose the elements constituting and determining the specificity of the club. This was made possible by the reification of club identity and the orientation towards the idea of social identity. At the same time, it should be stressed that objectification is not the same as the phenomenon of codification in the article, as it operates on a different level of interpretation, where a question related to the sense of identification, and not to commodification itself, is the foundation. Thus, El Clásico is not analyzed from the point of view of a brand created with the aim of launching on the market and generating profit, but by focusing on the effect of two entities that bind emotions of people all over the world (O'Brien, 2013). Aspects related to the issues of identification, sympathy and a high level of personal involvement do not, therefore, only take place within a single country, where this context has its foundations. Clubs operate their features in environments which, due to their differences and lack of rootedness in the system forming both teams, are not able to decode the assumptions forming their component.

The analytical process has been divided into three stages. The first one focuses on issues related to the definition of assumptions related to the reification issue and its connection with the concept of social identity in the context of a transnational community of supporters. The next step is to answer the question what elements of the club identity of Real and Barca have undergone the process of reification. Thus, the universal components that can function outside the Spanish space will be identified. At the same time, it is necessary to indicate the consequences of such actions, which are related to objectification, and therefore the statics of certain parts of identity. The last stage is the analysis of the indicated elements in terms of transnational activity of both clubs, taking into account the interdependence and opposites on which the individual activities are built. The overall analysis will necessarily take into account the Spanish environment, indicating the correlations between the two planes.

\section{Theoretical framework}

The issue of identity in the sports area very often refers to the constructive, reinforcing or complementary role played by a sport, its events or specific clubs, in relation to local, national or ethnic identity, which determines the formation of the community. The ongoing process, however, is two-way in nature, which means that by assigning values to a team and defining the basic group that the team represents, the identity of the club itself is automatically created. This kind of marking inextricably binds two groups together, which thus define each other's character. Based on the definition of Manuel Cas- 
tells, which describes as identical "the process of constructing meaning on the basis of a cultural attribute or a related set of cultural articles, which is given priority over other sources of meaning" (Castells, 2009: 21), the history of the community that forms the basis of the functioning of the team should be included among the elements that shape the club identity. Activists, players, reasons for the team's formation, difficulties, victories, defeats, venues for matches/competitions, symbols and main antagonists are among the most important elements influencing the specificity of a club and distinguishing it from other teams. Time has a fundamental value in this case - the longer the team's presence in the tournament, the more elements influence its perception and the more its image is rooted in society and the identity of the supporters. Therefore, it is problematic or at least risky to create new teams without a base in the form of a historical predecessor who could create an emotional bond with the newly formed team from the very beginning.

At this point, one can refer to the concept of social identity of Henri Tajfel and John Turner which is referred to by numerous researchers of correlations between sport and various areas of society's functioning. According to its assumptions,

we can conceptualize a group, in this sense, as a collection of individuals who perceive themselves to be members of the same social category, share some emotional involvement in this common definition of themselves, and achieve some degree of social consensus about the evaluation of their group and of their membership in it (Tajfel, Turner, 2004: 283).

At the same time, both researchers point out that the position and status of a group are fundamental to determining the place of an individual in society, with the individual always striving to maximize the importance of his or her own person, resulting in a desire to belong to a highly prestigious group (positive social identity) (Tajfel, Turner, 2004: 284). In this case, factors such as the community of fate, history or other elements are irrelevant - the key is to identify the factor determining the creation of a social group and activate the internal mechanisms present in such cells (favouring members, competition for leadership, etc.).

On the other hand, the reification of club identity is directly related to the need to preserve its symbolic character. As Ørnulf Seippel notes "sports become central symbols in modern societies' nationalism, by producing and, perhaps most important, activating the stories about who we are as members of countries" (Seippel, 2017: 45). The objectification of a fundamental social club component is a prerequisite for the ability to function in a globalized world and to build an international brand. Actions undertaken in this area may constitute a basis for codification, but only a correctly conducted process gives a real possibility to act. Establishing a permanent character of a given entity and an unambiguous symbolic meaning require the message to be stabilized. The aim of reification is therefore

to perceive human phenomena as if they were things, i.e. as inhuman or possibly superhuman. We can express this in another way, saying that reification is the perception of human creations 
as if they were something other than human creations - something such as natural facts, the results of cosmic laws or the manifestation of divine will (Berger, Luckmann, 1983: 123-127).

Thus, club identity loses its constantly created and permanent character, becoming a fully constituted unit, permanent and unchangeable. The image created by means of reification is only a final image, immobilized in a given moment of time for the needs of expansion outside a given social group. Referring to the concept of social identity, the elements created by the process of objectification, through historical and social filtration, offer an axiological collection to which individuals can refer regardless of their place of residence and belonging to different communities. As Krzysztof Arbiszewski notes:

The presented ranges become for an individual something 'external', which he or she no longer embraces as a series of conventions and habits, but has to learn as the existing shape of reality. Then the division into roles and the institutional landscape of the social world is found and external. There are conceptual resources for a ready-made convention on role and institution telling (Arbiszewski, 2016: 201).

El Clásico becomes a manifestation of a confrontation whose existence is granted from above, not considered on the basis of historical and political conditions. The center of gravity, which leads to emotional involvement on the part of one of the teams, is transferred to elements externalized from their identity.

In the case of sports clubs, which want to act simultaneously on the national and international level in the area of creating a community, actions are necessary which result in the identification of key elements requiring reification and, at the same time, enable the transformation of the others. This maintains a balance between the need for objectification and the option of evolving and developing the specificity of the team. It should be stressed at this point that the analysis carried out within the text does not refer to the level of identification of a supporter with a club. Both clubs and the specificity of their rivalry include all types of involvement, since it is this which, in the context of the concept of social identity referred to, determines membership of the community. Regardless of the factors that determine the willingness to participate and the strong emotions that a person has in relation to the club, the fan/supporter must be able to highlight and emphasize his or her status. That is why the marketing aspect, which produces products dedicated to each type of fan, is developed so strongly. As Balwant Samra and Anna Wos point out, consumer behaviour is one of the manifestations and elements consolidating a selected position and providing material identification attributes (Samra, Wos, 2014). However, club gadgets are only a visible sign of sympathy. This article focuses on the element preceding the decision to buy a Barca or Real scarf by residents of countries other than Spain. The analysis aims to determine why these teams are able to bind the emotions of people not connected with Spanish football, and the divisions between Blaugrana's and Los Blancos supporters are visible beyond the borders of this country. It is assumed that elements such as the high level of sport and the 
marketing power of both teams are important, but one of the most important factors is at the level of the identification component, which is the final element of the reification.

\section{Identity trap}

Blaugrana's fundamental role in the care of Catalan identity, analyzed by many researchers, was used by President Joan Laporta in the process of creating FC Barcelona as a brand with a specific message - mes que un club or "more than a club" (García, 2012). This specific combination of a marketing element with a sense of national representativeness, using all the elements determining, defining and expressing it (Husar, 2015) is, at the same time, a decision to reification of the entire club identity. In order for a product to be sold abroad, it became necessary to 'freeze' its value and highlight the elements that could become a source of identification or fondness for the club. The key to selling a brand is to establish an emotional bond with its potential customer - a component referring to the creation of a relationship, regardless of how much and for how long, is fundamental, as Bob Stewart, Aaron Smith and Matthew Nicholson emphasize in their analysis. They point out that "studies of sport consumption also show that the emotional connection that individuals have with a sport, team or player becomes more complex the deeper we look" (Stewart, Smith, Nicholson, 2003: 212). This means that a link of some kind, based on one of the numerous elements shaping the image and brand of the club, must be established and the consumer must react to the product offered to him.

The creation of FC Barcelona as an element and carrier of Catalanism is important in relation to the internal market of recipients who know the history of the club, the state and the relations prevailing in a specific environment. By functioning on this level, Barca only confirmed its role and strengthened it, especially in the context of Catalonia's aspirations for independence. Reification in this case stabilized certain links and permanently bound the club's activities in a certain direction, giving them a formal character. These activities gained in intensity after 2010 and the decision of the Constitutional Tribunal rejecting the provisions of the new statute of Catalonia - since then Blaugrana has no longer been merely an incubator of Catalanism, but one of the main representatives of the independence movement. The objectification, i.e. depriving the identity of the club of the element of dynamization and evolution, determines its unambiguous actions and, as it were, deprives it of the possibility of change. Barca cannot leave its position because any modification will cause the club's credibility among its sympathizers to decline. The created situation, therefore, results in imprisonment within the framework of a specific scheme of conduct, the change of which will overturn all the assumptions of the manufactured product. The created image and brand function independently of the people creating it, because the involvement of the Catalans and their perception of Barca is based on a deep emotional bond. This symbol has also been transferred to the international level, as Barca's treatment as the greatest ambassador and symbol of Cat- 
alonia closes it within the framework of current claims for independence. The involvement of not only the fans, but also the managers and, above all, the players themselves, modifies the meaning of Blaugrana as an incubator of Catalanism, reifying it as a symbol of civil disobedience in place of only a national symbol.

This transformation is also very visible on the sporting level. One of the fundamental elements shaping the identity of the club was a symbolic rivalry with Real Madrid. The political conflict found its safety valve in a specific way of competition and, taking into account sports and economic issues, it was a clue to the rivalry of both teams (Lopez-Gonzalez, Guerrero-Sole, Haynes, 2014). FC Barcelona's activities broke the existing principle of exposing and playing the conflict mainly in the sports (symbolic) sphere, engaging in a significant way in direct political actions aimed at gaining independence. A similar activity, however, cannot be observed on the side of Real Madrid, which used the conflict situation with Blaugrana to build its potential, but instead of linking its identity with national aspects, focused on exposing its cosmopolitan character, which has become particularly visible since Fiorentino Perez became the president. Perceiving the rivalry between the Los Blancos and Barca in terms of national and political conflict was a legacy that could be used in the marketing area, and so this division was perpetuated at the stage of reification and the creation of plans for international expansion. The gap in the perception of this situation is visible in the supporter community itself: the reading of the relationship between Real and FC Barcelona as political is particularly present among older supporter groups. For younger fans, it is mainly the expression of the message and the opportunity to demonstrate civil disobedience that is important. They see the rivalry itself as an inter-city and inter-club fight for dominance, not a national conflict (Barceló et al., 2015).

\section{Making a special bond - strategy of identification}

A different situation takes place at the international level, which results from the lack of emotional involvement in the social, historical and political conditions determining the behaviour of Spaniards and Catalans. The reification strategy is based on the fact that the community, and therefore the emotional bond, had to be based on other factors. One of the elements enabling its creation is, in the case of the FCB, the La Masia football school and its worldwide counterparts. According to data for 2018, FCB Escola training points were located on five continents with a total of 33 (Escuelas del Barça, 2017). Barca, thus, affects a wide range of audiences who feel attached to it because of the opportunities it offers for development and its constant presence in the local environment. Thus, despite the lack of an element of historical or national community, FCB performs a specific transplant of its identity by means of a transfer of an element essential for the functioning of the club. Thus, despite the different backgrounds, it is possible to blur the original division between 'we' and 'they', because 'they' becomes 'us'. Fer- 
dando Carrión Mena stresses that there are many different reasons for identifying with a given team, mentioning eight fundamental ones. One of these is identification with the player, which is the result of the strong exposure of the individual to football. A footballer becomes a specific symbol, representing certain values such as age, social group or nationality. Admiration, identification or simple sympathy for a particular player is transferred to the team in which he plays (Carrión Mena, 2006). Analyzing the FC Barcelona case from the point of view of the different origins of players, it can be said that it was described as one of the most international clubs in the Spanish league (Llopis Goig, 2008). Extrapolating from these two premises it can be assumed that the presence of players from other countries in Barca's team may have contributed to increasing the popularity of the club outside Spain. A similar situation was observed in the case of Real Madrid, which during the period defined as los Galacticos employed the best players in the world, including France, Brazil, Portugal and England. Each of them enjoyed high esteem in the national fan community, which, based on the following assumptions, could translate directly into increased sympathy for the club.

An interesting exception in this area is the Argentinean, Lionel Messi, who enjoys much more respect and sympathy among FC Barcelona fans than in his home country. In his case, the main focus is on his sporting career, which in Argentina lasted for a relatively short time, because at the age of 13 Messi moved to Spain and started training in La Masi. Bartłomiej Brach notes that:

Messi is a hybrid many Argentinean fans would prefer to keep at a distance, since his career path undermines the myth of criollo football, which was constructed on the premise of the adaptation of Southern European immigrants to the local environment. Many of them despise the fact that the best Argentinean player, the one to become the new Maradona, is the other. This is probably the source of fans calling him The Catalunyan or emphasizing his inability to sing the national anthem. what is more, due to the fact that he did not flourish in Argentina, Messi does not have a considerable group of locals backing him up in the press discourse (Brach, 2012: 422).

The history of Messi's career does not fit in with the national path of young football players, who often gain a symbolic status in the state - pibe or a young boy from the working class, playing on a potrero, meaning places (trampled areas of land the size of a football pitch), where he trains his skills to later become a national pride (Sibaja, Parrish, 2014). In this case, we are dealing with the opposite situation, when too much identification with the club contributes to limiting the sympathy through antipathy to a specific player. At the same time, Messi's story shows the importance of the factor of group identification through a community of fates - Argentines do not find in his past the points linking him to the traditional model of football development and, therefore, are not able to treat FC Barcelona's player, despite his outstanding achievements, equal to the Argentinean symbol, which is Diego Maradona (Alabarces, 2013).

In the discussed context of the relationship between sympathy for a given player and sympathy for the club, it is also worth mentioning the importance of the concept of 
a sports hero. In the national context, as in the case of Messi, it is important to have a social reality and to be part of a specific career development model - the more points of contact, the greater the sympathy and representativeness. As Keith D. Parry )points out, athletes of different nationalities are also sporting heroes. The key factor is that "heroes should be people who society can look up to and try to emulate; they should in essence be good role models for society" (Parry, 2009: 213-214). His 2009 study of sporting heroes in the UK showed that David Beckham enjoyed the greatest esteem, but he was also often mentioned as the Arsenal London star Thierry Henry. On an international level, as is the case with the structure of the majority of football teams, the skills and characteristics of a player are much more important than his nationality. Moving this to the area associated with the rivalry between Real Madrid and FC Barcelona, the main players determining this competition for many years were Christiano Ronaldo and Lionel Messi. Recognized as the best players of the time, they determined the interest of fans and the division into supporters of Real or Barcelona, but it should be noted that none of them (despite the treatment of Messi on an equal footing with native players) comes from the territory of Spain. In this case, the individual characteristics of the player were predominant, with comparability not only in terms of football skills.

In the context of building international sympathy, it is however worth mentioning the role of the Spanish part of the composition of both teams. The success of the national team at the World Cup 2010 resulted in the evaluation of the perception of players, while most of the players from the first team were clearly associated with Real (Iker Casillas, Sergio Ramos, Xabi Alonso) or Barcelona (Gerard Pique, Charles Puyol, Sergio Busquets, Xavi, Address Iniesta, Pedro and later David Villa). The players of both teams, regardless of how entangled in the national perception of inter-club competition, became representatives of a reified image of the team, which drew on the historical conflict, but used it more as a tool, and not as a real antagonism:

FCB's playing style, seed of Spain national team's playbook, is considered to be offensive, spectator-friendly, focusing on the passing game and ball possession, and favouring small-sized but extremely virtuous footballers. RMD, on the contrary, has abandoned the glow of the early 2000s - with players such as Figo, Zidane or Roberto Carlos - and, particularly since the arrival of Mourinho, has become a more conservative and straight forward football squad. In summary, a vast amount of talent and ambition, memory and grudge, both in the field and the bench, is assembled every time these two teams play against each other: an ideal environment for dispute and conflict (Lopez-Gonzalez, Guerrero-Sole, Haynes, 2014: 691).

This situation is immanently connected with the specificity of the sports market, resulting from transfer windows, players' decisions to move or to include new players in the line-up. The high level of internationalization of teams is not a new phenomenon, but it is important from the point of view of building relations with supporters of other nationalities. In the perspective of building a strategy for Real, President Fiorentino 
Perez selected two types of players, each of whom, similarly as in the case of FCB, performed different functions:

In this category, it is possible to differentiate two kinds of football players: firstly, players like Raul or Casillas (developed in Real Madrid's nursery) that are long-term resources, whereas players such as Beckham, Ronaldo, or Zinedine Zidane (signed up when they were already famous world football players) that are short-term resources. Although both kinds of resources are scarce in the market and fulfill the consumer demand, the former can be considered as specific to the Real, whereas the latter are not specific. The specificity refers to the value of a resource in alternative uses (in this case, sports clubs) and determines the distribution of profits among players and clubs (Blanco Cajero, Forcadell, 2006: 61-62).

It is also worth noting that both Real and Barca are the clubs that employed the largest number of foreign players in the Spanish league. As Jorge Tunón and Elisa Brey emphasize, it has never contributed to a decrease in the identification of Spanish fans with the team, who treated foreign players as representatives of symbolic values (Tuñón, Brey, 2012: 24). Ramón Llopis Goig's research also seems to confirm the above assumptions. According to its results, $38 \%$ of the Spanish, declaring themselves to be football supporters, are in favour of Real Madrid, while $18 \%$ are in favour of FC Barcelona. As far as the group identifying themselves with Blaugrana is concerned, $53 \%$ consider it to be a representative of Catalanism, while $21 \%$ are only supporters of it because of aspects related to the specificity of the team (Llopis Goig, 2006). From this perspective, Luis Figo betrayed Barcelona in a double way - he renounced the values he represented (although he was not a junior player of the club, but an external player) and additionally renounced them despite the fact that he was a team captain, which, given Barca's importance, put him high in the hierarchy of Catalan ambassadors. Assuming the premise of the cosmopolitan identity of Real, however, Figo's past was not a problem - the value in itself was the player's potential and his recognition and esteem throughout the world.

Selection of the squad is important because it does not only decide about the creation or transfer of a bond between a player, club and a supporter. It also determines the perception of the work ethos and success, which is comparable to the already mentioned Argentinean model. The cosmopolitan Real with its star team was based on a strategy called "Zidanes y Pavones", which meant a large percentage of famous players or the simultaneous hiring of young players to help without the so-called workhorse players (Kase, Gomez, Urrutia, Opazo, 2007). In the same period, FC Barcelona put emphasis on the team based on a few stars (Ronaldinho or Samuel Eto), which were supported by alumni from La Masia, as mentioned above Messi. This approach was based on the assumption that strong sympathy for the club, resulting from its system of functioning and the source of success, will last longer than the sympathies built on the popularity of one player (Hamil, Walters, Watson, 2010). Thus, the individualistic concept of los Galacticos was contrasted with Blaugrana's teamwork. Analyzing the adopted approach, one can see that the political conflict is exposed on the basis of two implemented sys- 
tems - a club that is successful thanks to money invested in foreign stars versus a team built from scratch, in which the chance for success results from the hard work of the whole team. Based on the above assumption, the sympathy for Blaugrana was supported by its story, according to which Real was the favorite team, while Barca could only rely on its own resources - in such a comparison, empathy worked in favour of the team from Catalonia. The universal and transnational character of this type of differentiation made it possible to identify outside Spain, because it did not require knowledge of the specificity of the conflict - the mere fact of its existence and the possibility of comparing it with the strategy of the main antagonist was sufficient. Barca also benefited from a strong involvement in the third sector, in particular the availability of a seat on UNICEF's club shirts (Giniesta, Ordeix, 2012).

\section{Conclusions}

Externalization of the conflict outside Spain was connected with the need to redefine the meaning of the traditional carrier of both clubs. In a transnational context, the symbolic dimension carried by El Clasico is only relevant in the context of the created antagonism, since at the emotional level, external entities are not able to decode the context correctly. Therefore, by giving the club's identity static elements, it became possible to transpose a national event into transnational ones. The conflict between the clubs did not lose its intensity, but through expansion into external markets it became necessary to simplify the message and, at the same time, to implement mechanisms enabling building relations with the inhabitants of other countries. The consequence of building the message based on antinomies with the main antagonist, combined with strategies of universalization of values and internal internationalization, is permutation of rivalry between Barca and Real. The transformation of this confrontation in relation to itself can be described as a natural result of the chosen tactics, but the need for a balanced and simultaneous development of both clubs should be stressed. Sporting performance is an important element of interest, but 1) one of the clubs has a significant and longterm advantage or 2) a change in the elements underlying the reification could result in a change in the approach to El Clásico. An example is the possibility of a slight modification of Barca's and Real's position on the issue of independence of Catalonia, which would result in a complete distortion of the image that has been created so far. The national component is therefore crucial for maintaining the status quo in the transnational space, guaranteeing the stability of the created image. 


\section{Bibliography}

Alabarces P. (2013), Fútbol, leonas, rugbiers y patria. El nacionalismo deportivo y las mercancías, "Nueva Sociedad", No. 248.

Arbiszewski K. (2016), My jako podmioty społecznie konstruowanej wiedzy. Reinterpretacje i uzupetnienia fenomenologii społecznej Petera Bergera $i$ Thomasa Luckmanna, „Filozofia i nauka. Studia filozoficzne i interdyscyplinarne", No. 4.

Barceló J., Clinton P., Samper Seró C. (2015), National identity, social institutions and political values. The case of FC Barcelona and Catalonia from an intergenerational comparison, "Soccer \& Society", No. 16(4), DOI: https://doi.org/10.1080/14660970.2014.882826.

Berger P., Luckmann T. (1983), Społeczne tworzenie rzeczywistości, Warszawa.

Blanco Cajero M., Forcadell F. (2006), Real Madrid football club: A new model of business organization for sports clubs in Spain, "Global Business and Organizational Excellence", No. 26(1), DOI: https://doi.org/10.1002/joe.20121.

Brach B. (2012), Who is Lionel Messi? A comparative study of Diego Maradona and Lionel Messi, "International Journal of Cultural Studies", No. 15(4), DOI: https://doi. org/10.1177/1367877911422859.

Carrión Mena F. (2006), El fútbol como práctica de identificación colectiva, [in:] Area de candela. Futbol y literatura, edit. R. Pérez Torres, Quito.

Castells M. (2009), Siła tożsamości, Warszawa.

El Clasico: El partido planetario (2019), https://elpais.com/publi-especial/barcelona-real-madrid-clasico/ [access on: 7.08.2019].

Escuelas del Barça en los cinco continents (2017), https://www.mundodeportivo.com/futbol/ fc-barcelona/20170406/421502314660/escuelas-barca-mundo.html [access on: 9.08.2019].

García C. (2012), Nationalism, Identity, and Fan Relationship, "International Journal of Sport Communication", No. 5(1), pp. 1-15.

Giniesta X., Ordeix E. (2012), El fútbol profesional y su responsabilidad social corporativa en Cataluña (2006-2010). Mucho más que Unicef, "Contratexto", No. 20, DOI: https://doi. org/10.26439/contratexto2012.n020.178.

Hamil S., Walters G., Watson L. (2010), The model of governance at FC Barcelona:balancing member democracy, commercial strategy, corporate social responsibility and sporting performance, "Soccer \&Society", No. 11(4): DOI: https://doi.org/10.1080/14660971003780446.

Husar W. (2015), Komodyfikacja Fútbol Club Barcelona i wykorzystanie elementów katalońskości jako wartości dodanej brandingu, "Annales Universitatis Mariae Curie-Skłodowska, sectio K", No. XXII(2), DOI: https://doi.org/10.17951/k.2015.22.2.149.

Informe Annual Real Madrid (2019), https://www.realmadrid.com/socios/carnet-de-socio/informes-anuales [access on: 5.08.2019].

Kase K., Gomez S., Urrutia I., Opazo M. (2007), Real Madrid CF - FC Barcelona: Analysis of Business and Sports Strategy During the Period 2000-2006, "SSRN Electronic Journal”, No. 6(12), DOI: https://doi.org/10.2139/ssrn.975912.

Lopez-Gonzalez H., Guerrero-Sole F., Haynes R. (2014), Manufacturing conflict narratives in Real Madrid versus Barcelona football matches, "International Review for the Sociology of Sport", No. 49(6), DOI: https://doi.org/10.1177/1012690212464965. 
Llopis Goig R. (2006), Clubes y selecciones nacionales de fútbol . La dimensión etnoterritorial del fútbol español, "Revista Internacional de Sociologia", No. LXIV(45), pp. 37-66.

Llopis Goig R. (2008), National orientation, universal outlook - the symbolic capital of FC Barcelona in the global era, "European Journal for Sport and Society", No. 5(1), DOI: https://doi.org/10 .1080/16138171.2008.11687809.

Memoria 2018/2019 FC Barcelona (2019), https://www.fcbarcelona.com/en/club/organisation-and-strategic-plan/commissions-and-bodies/annual-reports [access on: 2.09.2019].

O'Brien J. (2013), 'El Clasico' and the demise of tradition in Spanish club football, "Soccer \& Society", No. 14(3), DOI: https://doi.org/10.1080/14660970.2013.801263.

Parry K. (2009), Search for the hero: an investigation into the sports heroes of British sports fans, "Journal Sport in Society Cultures.Commerce, Media, Politics", No. 11(2), DOI: https://doi. org/10.1080/17430430802591001.

Ruiz D., Martiarena A. (2012), Alfredo Relaño: "El Barça es un ámbito sentimental y el Madrid un instrumento de conquista", https://www.lavanguardia.com/deportes/barsa-madrid/20120419/54284589208/alfredo-relano-barsa-madrid.html [access on: 30.08.2019].

Samra B., Wos A. (2014), Consumer in Sports: Fan typology analysis, "Journal of Intercultural Management”, No. 6(4), DOI: https://doi.org/10.2478/joim-2014-0050.

Seippel Ø. (2017), Sports and Nationalism in a Globalized World, "International Journal of Sociology”, No. 47(1), DOI: https://doi.org/10.1080/00207659.2017.1264835.

Sibaja R., Parrish C. (2014), Pibes, Cracks, and Caudillos: Argentina, the World Cup, and Identity Politics, "Soccer \& Society", No. 15(5), DOI: https://doi.org/10.1080/14660970.2014.912017.

Stewart B., Smith A., Nicholson M. (2003), Sport consumer typologies: A critical review, "Sport Marketing Quarterly", No. 12(5), pp. 206-216.

Tajfel H., Turner J. (2004), The Social Identity Theory of Intergroup Behavior, [in:] Key readings in social psychology. Political psychology: Key readings, edit. J. Jost, J. Sidanius, New York.

Tuñón J., Brey E. (2012), Sports and Politics in Spain - Football and Nationalist Attitudes within the Basque Country and Catalonia, "European Journal for Sport and Society", No. 9(1-2), DOI: https://doi.org/10.1080/16138171.2012.11687887.

\begin{abstract}
The presented article focuses on the analysis of the transposition of a national event into supranational one, the most striking example of which is the confrontation of Real Madrid with FC Barcelona, known as El Clásico. The text will examine the elements used in the process of recasting the event, which are decisive for giving it a meaning beyond the framework of a single country. The hypothesis is as follows: "While still functioning in the Spanish symbolic space, Real Madrid and FC Barcelona have transposed the mutual rivalry through permutation of the national event into supranational one, using elements that constitute and determine the specificity of the club. It was possible through reification of identity and orientation towards the idea of social identity". It indicates the direction of research, which differs from treating this phenomenon only in marketing terms. It also outlines two basic points of reference, focusing the analysis on aspects related to identification issues. These, as will be shown in the text, determine the possibility of emotional involvement of supporters all over the world in experiencing a national holiday such as the confrontation of the Los Blancos and Blaugrana, without having to decode the primordial component which is political and social conflict. Keywords: El Clásico, national sport events, sport, reification, social identity
\end{abstract}

